\title{
Effect of Industrial Effluents on Chemical Composition of Agriculture Soil in Indore (M.P.)
}

\author{
Jaiswal Payal $^{1}$, Dave Jyoti ${ }^{2}$ \\ School of Biochemistry, DAVV, Indore M.P. ${ }^{1}$, Department of Bio-Sciences, Shri Cloth Market Institute of \\ Professional Studies, Indore M.P. ${ }^{2}$ \\ E-mails-jpayal96@gmail.com1,davejyoti9@rediffmail.com ${ }^{2}$
}

\begin{abstract}
Mineral (primary, intermediate and micro-nutrients) are important factors for plant and needed in optimum amount for proper growth and development of plant. Any imbalance in the composition of minerals is injurious to plant growth and can cause serious problems. In this study we detect the concentrations of various minerals in the soil which is contaminated by industrial effluent and compare it with organic soil (control) and discuss the effect of mineral excess \& mineral deficiency on plant growth.
\end{abstract}

Keywords: Organic soil, Polluted soil, Industrial effluent, Mineral deficiency, Mineral Excess.

\section{INTRODUCTION}

A healthy soil is mixture of various components like minerals $(45 \%)$, organic matters $(5 \%)$, air $(20-30 \%)$, liquid (20-30\%) and microorganisms. These all component makes soil very important for humans, animals and plants. As soil provides medium for the growth of plants which are very essential for the humans, animals and of course for our environment, it also has water holding capacity and provides habitat for various organism \& microbes.

Organic soil is rich in organic matters, means it consist of dead plant materials, microorganisms etc. it is rich in minerals, various nutrients like nitrogen and phosphorus which are very essential for the plant growth. Organic matter present in soil improves soil structure and also water holding capacity, and makes plant healthy as compare to plants which are grown in polluted soil or soil contain various insecticides and pesticides. In organic field farmers use traditional and nonchemical methods to control insects to make soil chemical free.

A polluted soil or we also can say contaminated soil is a result of human made waste, chemicals, domestic waste, agriculture waste like pesticides \& insecticides, and most importantly industrial waste which is one of the major causes of soil pollution in present days due to higher level of urbanization. The polluted soil affects in both the way directly and indirectly to health of human, animals and plant as well. Contaminated soil consist different pollutants that affect health but the heavy metal contamination is the major drawback of industrial pollutants. Different studies show that industries like leather industry, pharmaceuticals, fertilizers, coal mines, and other heavy industries are the main reason of heavy metal pollution in soil, which decreases productivity of soil and thus causes reduction in crop yielding.

\section{MATERIAL \& METHODS}

For the present study organic soil was collected from a Organic farm at Rangwasa near Rau, Indore where plants are grown by using completely organic methods and we used it as a control. The polluted soil is a test soil which is contaminated with industrial effluent and is collected from a field at Bhangad region near MR-10 Indore. We will be using plants grown in this soil to study different parameters and activities like growth, biochemical parameters and antioxidative activities etc. We conducted a pilot study to compare different mineral content $(\mathrm{N}, \mathrm{P}, \mathrm{K}, \mathrm{Ca}, \mathrm{Mg}, \mathrm{S}, \mathrm{Zn}, \mathrm{B} . \mathrm{Fe}, \mathrm{Mn}$ and $\mathrm{Cu}$ ) between organic and test soil. In this study we showed comparison between soils. 
International Journal of Research in Advent Technology, Vol.7, No.5, May 2019

$$
\text { E-ISSN: 2321-9637 }
$$

Available online at www.ijrat.org

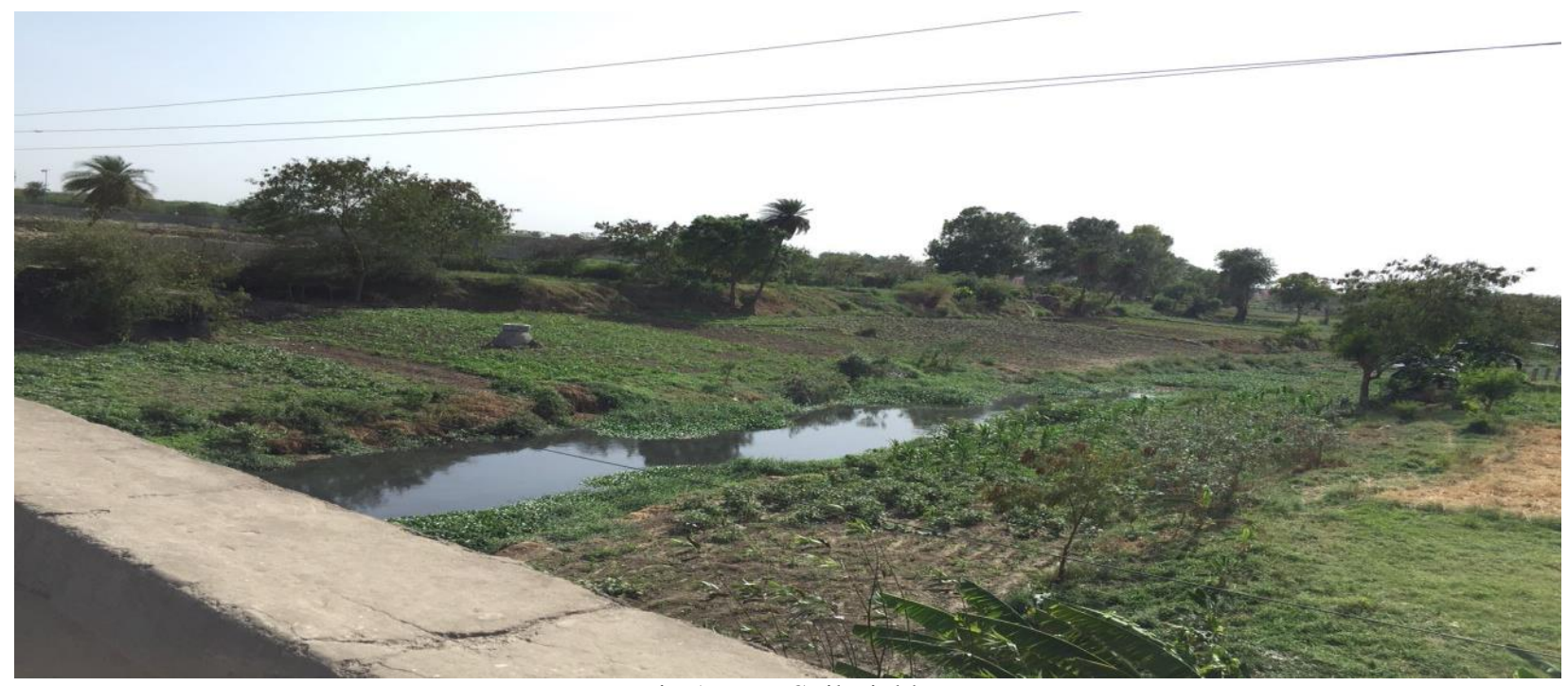

Fig.1. Test Soil Field

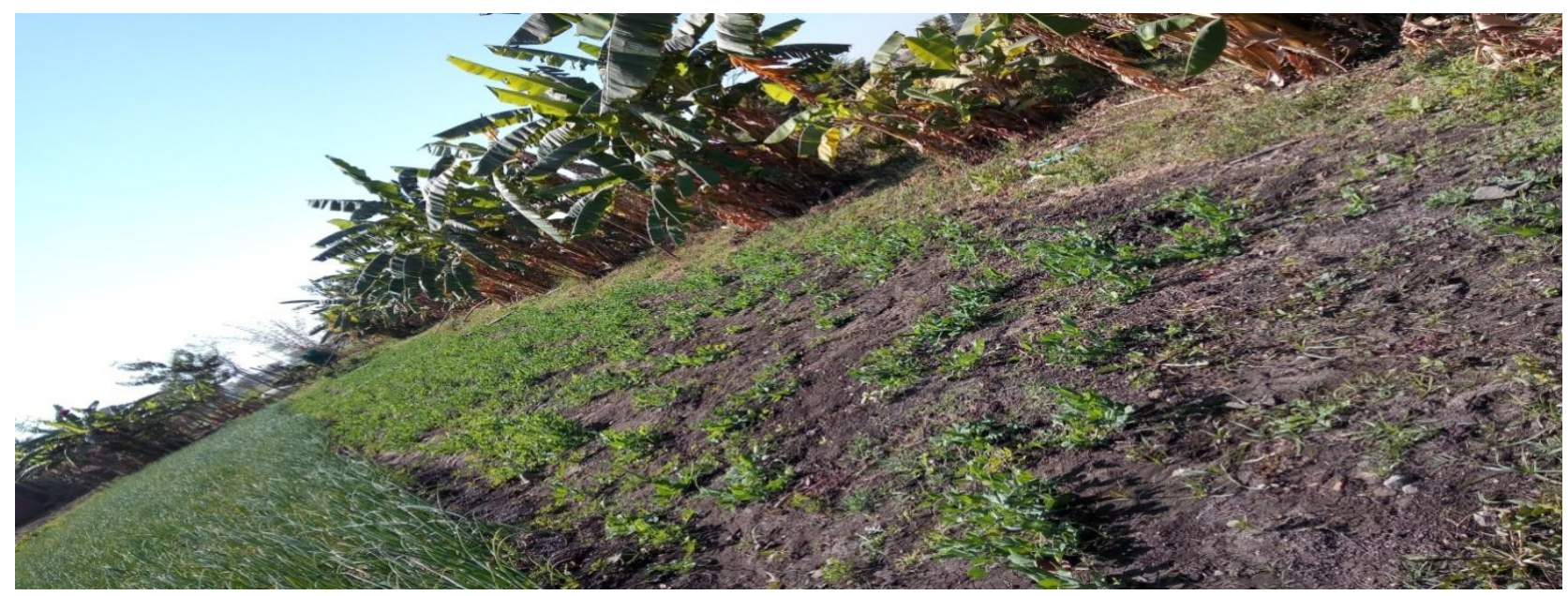

Fig.2. Organic soil field

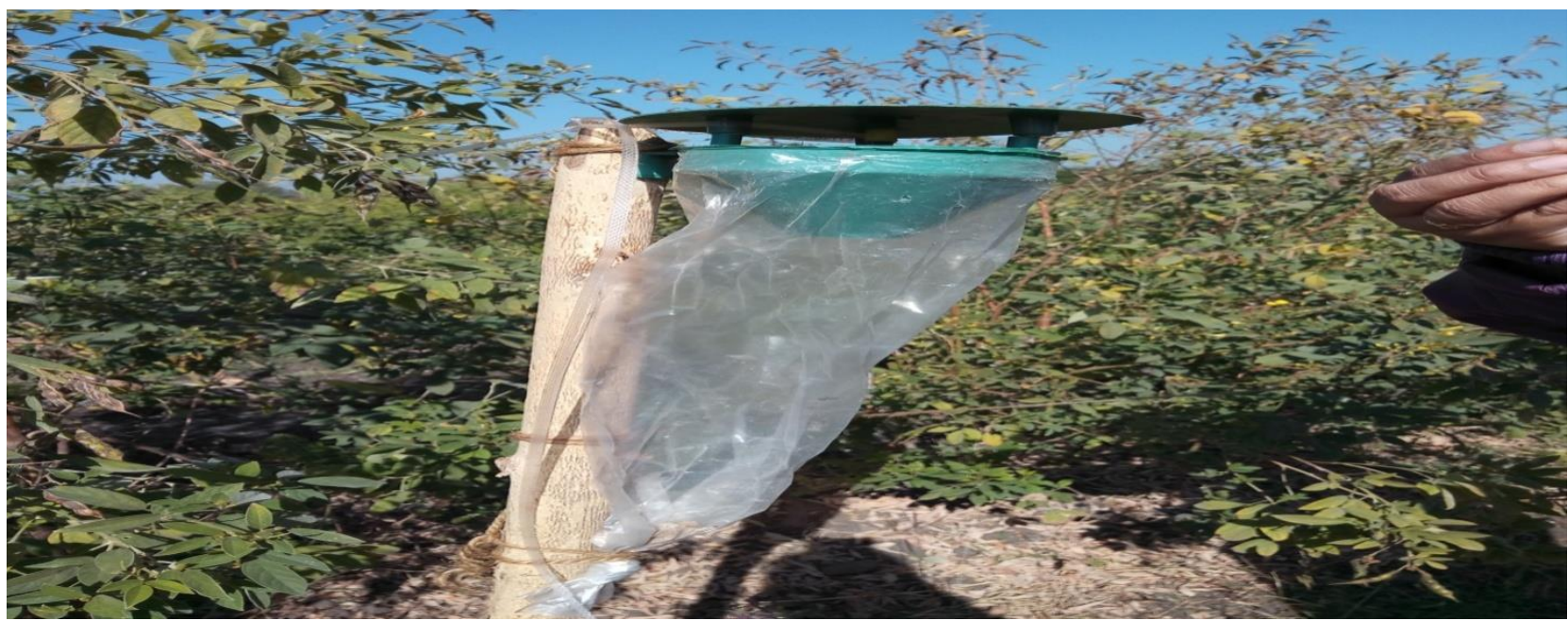

Fig.3. Organic Soil Field 


\section{International Journal of Research in Advent Technology, Vol.7, No.5, May 2019 E-ISSN: 2321-9637 Available online at www.ijrat.org}

2.1. Methods used for the minerals estimation in soils: 2.1.1. Nitrogen content: Estimation of the mineralizable or available $\mathrm{N}$ content of the soil by alkaline permanganate method outlined by Subbiah and Asija (1956).

2.1.2. Phosphorus content: Available phosphorus content of soil was estimated with Olsen method, the transmittance or absorbance of the blue color so developed was read after 10 minutes, on spectrophotometer (model-2371) at $730 \quad \mathrm{~nm}$ wavelengths.

2.1.3. $\mathrm{K}$ content: Estimation of the available ' $\mathrm{K}$ ' content in soil by flame photometry (model-1382).

2.1.4. $\mathrm{Ca}$ and $\mathrm{Mg}$ content: Estimation of the available ' $\mathrm{Ca}$ ' and ' $\mathrm{Mg}$ ' content in soil by flame photometry (model-1382)
2.1.5. Sulfur content: Sulphur is present in organic and inorganic forms. The amount depends upon the parent material, soil organic matter status and texture of the soil. Plants absorb sulfur in the form of sulphate ion $\left(\mathrm{SO}_{4}{ }^{-2}\right)$. A large number of extractants like $\mathrm{H}_{2} \mathrm{O}$; monocalcium phosphate; $\mathrm{CaCl} 2$; a mixture of ammonium acetate and acetic acid and $\mathrm{NaCl}$ have been used for extraction of available $\mathrm{S}$. Among the different extractants $\mathrm{CaCl}_{2}(0.15 \%)$ was found to be the best extracting as suggested by Williams and Steinbergs in 1959.

2.1.6. $\mathrm{Fe}, \mathrm{Mn}, \mathrm{B}$, and $\mathrm{Zn}, \mathrm{Cu}$ content in soil: $\mathrm{By}$ using DTPA (diethyline-triamine penta acetic acid) reagent. The content of metal was determined with the help of an AAS (SL-176)

3. RESULT

Table-3.1.Comparison between primary nutrient, intermediate nutrient and micro nutrient of organic \& test soil:

\begin{tabular}{|c|c|c|c|c|}
\hline Minerals & Normal content & Organic soil & Test soil & \% Change \\
\hline Nitrogen $(\mathrm{Kg} / \mathrm{H})$ & $251-400$ & 198 & $347^{*}$ & 0.75 \\
\hline Phosphorus(Kg/H) & $11-20$ & 4.99 & $56^{*}$ & 10.22 \\
\hline Potash(Kg/H) & $251-400$ & 230 & $1049^{*}$ & 3.56 \\
\hline Calcium(Kg/H) & $101-5625$ & 12006 & $5936^{*}$ & -0.50 \\
\hline Magnesium(Kg/H) & $180-1350$ & 414 & $552^{*}$ & 0.33 \\
\hline Sulfur(Kg/H) & $20-30$ & 4.8 & $14.1^{*}$ & 1.93 \\
\hline Zinc $(\mathrm{ppm})$ & 0.60 & 0.48 & $0.38^{*}$ & -0.20 \\
\hline Boron(ppm) & 0.50 & 0.34 & $0.28^{\mathrm{NS}}$ & -0.17 \\
\hline Iron $(\mathrm{ppm})$ & 4.50 & 4.9 & $4.82^{\mathrm{NS}}$ & -0.01 \\
\hline Manganese(ppm) & 1.00 & 1.3 & $1.10^{\mathrm{NS}}$ & -0.15 \\
\hline Copper(ppm) & 0.20 & 0.2 & $0.32^{\mathrm{NS}}$ & 0.6 \\
\hline
\end{tabular}

Normal content is according to agriculture department ${ }^{\mathrm{s}} \mathrm{p}$-value $>0.05$ is not significant. ${ }^{*} \mathrm{p}$-value $<0.05$ is significant as compare to organic soil.

\section{Primary-Nutrients}

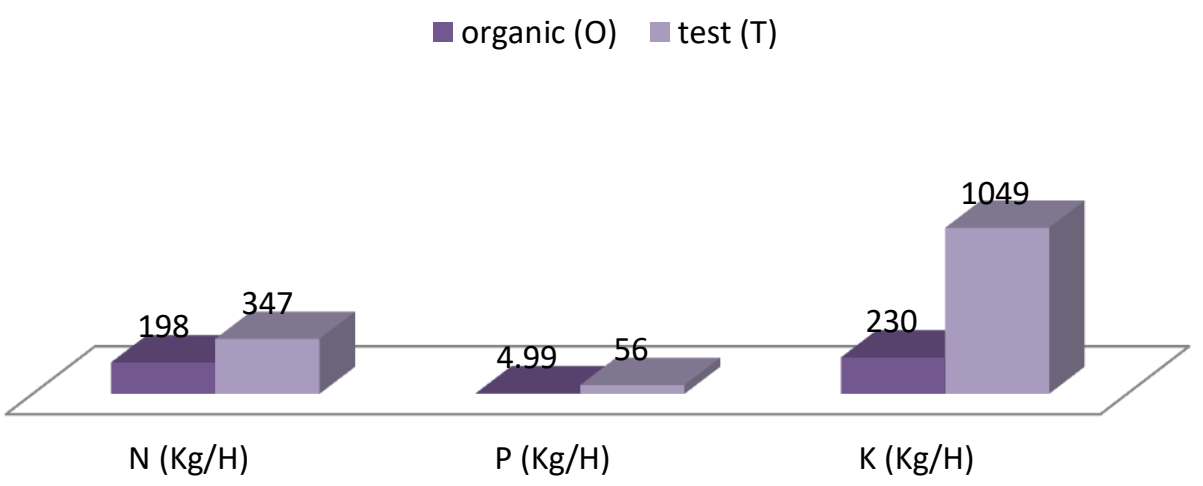

Fig.4. Comparison between Primary nutrient content of Organic and test soil. 
International Journal of Research in Advent Technology, Vol.7, No.5, May 2019

E-ISSN: 2321-9637

Available online at www.ijrat.org

\section{Intermidiate-Nutrients}

$\square$ organic $(\mathrm{O}) \quad$ test $(\mathrm{T})$

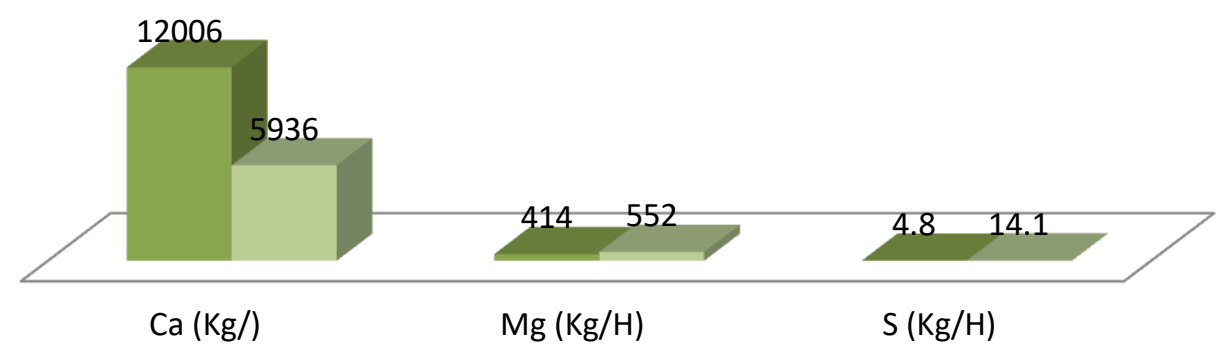

Fig.5. Comparison between Intermediate nutrient content of Organic and test soil.

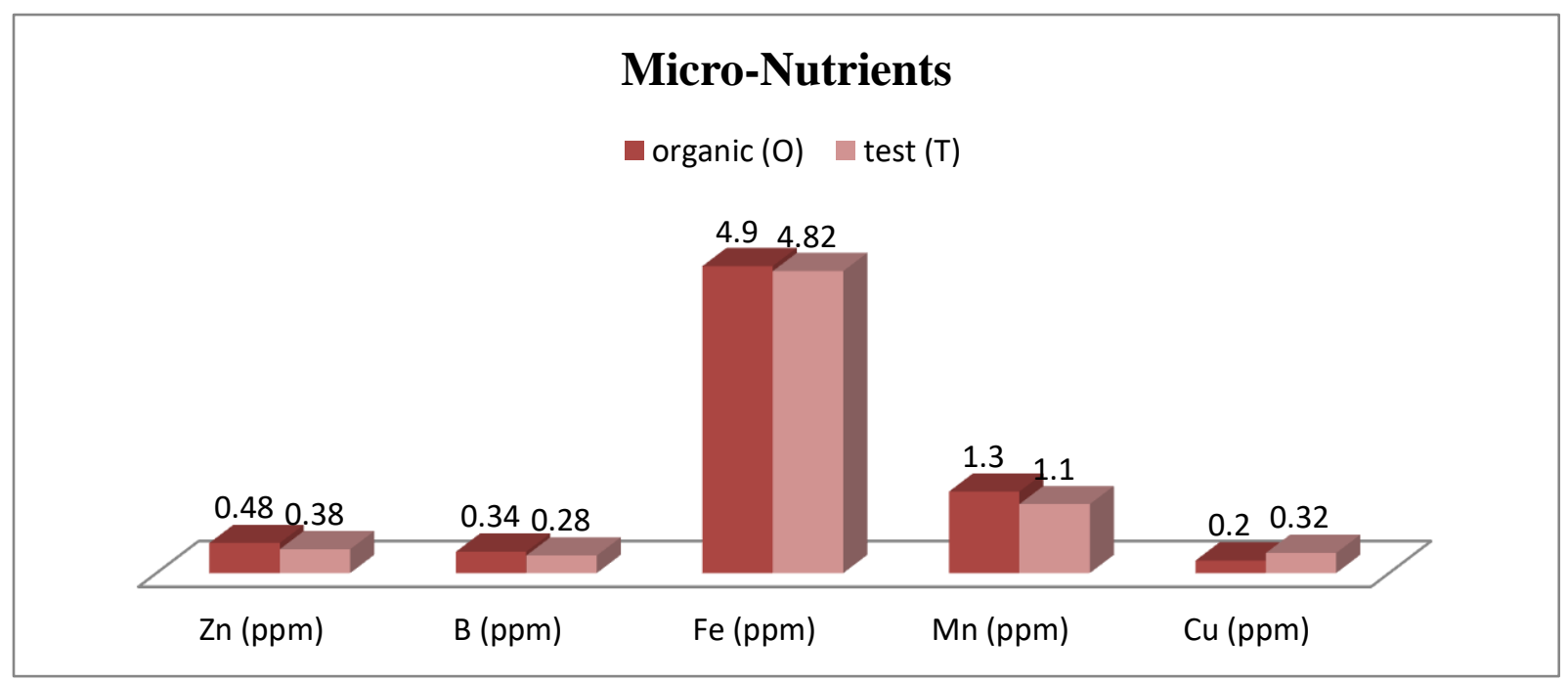

Fig.6. Comparison between Micro-nutrient content of Organic and test soil.

\section{DISCUSSION}

All the nutrients are in optimum concentration are essential to make the soil healthy and are required for proper plant growth. Their deficiency can be cured by giving organic manure, fertilizers etc. but due to lack of knowledge, farmers use excess amount of fertilizers without soil testing for particular plant that they want to grow. In this study our test soil which is treated by water contaminated by industrial effluents already contains higher amount of nutrients. But fertilizers are also added by farmers without soil testing which exploits the quality of soil and crops as well.

$\mathrm{N}, \mathrm{P}$ and $\mathrm{K}$ are the primary nutrients for the plants. Nitrogen is the most important component for plant growth. It provides several benefits to plant like appropriate growth of flowers, shoot, leaves and vegetables, as we know $\mathrm{N}$ is a part of chlorophyll molecule, which is necessary for photosynthesis. High content of $\mathrm{N}$ causes some stability issues, leaching nutrients and over stimulating top growth. In present study test soil contain significantly increased amount of $\mathrm{N}$ as compare to organic soil and normal value, it may be due to industrial and domestic waste which will cause adverse effect of high $\mathrm{N}$ content on plant and human health also.. In present study phosphorus significantly increased in test soil as compared to organic soil. Phosphorus is needed for cell division and promotes growth, root formation, and flowering etc. $\mathrm{P}$ is 


\section{International Journal of Research in Advent Technology, Vol.7, No.5, May 2019 E-ISSN: 2321-9637 Available online at www.ijrat.org}

also important for the metabolism of different biomolecules in plant and it stored in fruits and seed, present study was supported by Razaq M.et. al. (2017) who suggested that $10 \mathrm{~g} \mathrm{~N}$ and $8 \mathrm{~g} \mathrm{P}$ were found to yield maximum growth, and the maximum values of plant height, root collar diameter and chlorophyll content. In present study $\mathrm{P}$ content is higher than normal, in excess amount $\mathrm{P}$ have adverse effect on growth plant as it interferes with absorption of other minerals like $\mathrm{N}, \mathrm{Zn}$, $\mathrm{Fe}, \mathrm{Co}$ and $\mathrm{Ca}$, plant shows deficiency symptoms of these nutrients. If this excess $\mathrm{P}$ riches to water sources that accelerate the growth of algae, when these algal dies it decomposes using $\mathrm{O}_{2}$ and hence increases BOD and cause adverse effect on aquatic animals.

Potassium is second essential elements for the plant after N. as it plays several function in plant, it is imp for the growth and reproduction in balanced amount. In present study Potassium significantly increased in test soil as compare to organic soil. In excess quantity it interferes with absorption of $\mathrm{Mg}$ and $\mathrm{Mn}$, and develops their deficiency symptoms in plan. Present study was supported by CarmeisFilhoet.al.(2017). Who reported that increased concentration of potassium affects shoot and root dry matter, diameter and length density, it also reduces shoot calcium and magnesium concentration.

Intermediately nutrients like $\mathrm{Ca}, \mathrm{S}$, and $\mathrm{Mg}$ are also important for the proper growth of plant which is provided by soil of course. In present study calcium significantly decreased in test soil as compare to organic soil. Calcium is important for the growth, it is the component of cell wall and perform several function in plant like chemical balance, reduce soil salinity, improves water penetration etc. present study supported by Tabatabaeian J.et.al. (2013) who concluded that increased salinity Caused significant reduction in water content of tissues, cytoplasmic membrane stability and chlorophyll concentration. In excess amount $\mathrm{Ca}$ decreases the absorption of $\mathrm{N}, \mathrm{P}, \mathrm{K}, \mathrm{Mg}$ and also the micronutrients ( $\mathrm{B}, \mathrm{Zn}, \mathrm{Cu}, \mathrm{Fe}$ etc.) and plant shows their deficiency symptoms.

In present study Magnesium content is normal in both organic and test soil but increased significantly in test soil as compare to organic soil. $\mathrm{Mg}$ has positive impact on photosynthesis, activation of enzymes, formation and utilization of ATP and promotes the growth of root and shoot. Present study was supported by Cakmak I.(2013) who reported that $\mathrm{Mg}$ nutrition is required for better crop yields under adverse condition and also suggest that presence of soluble $\mathrm{Mg}$ in soil also needed to avoid $\mathrm{Mg}$ deficiency risk ( grass tetany) and to improve productivity of grazing animals. in excess $\mathrm{Mg}$ interferes with the absorption of other nutrients and affects the plant growth. High content of $\mathrm{Mg}$ also has adverse effect on human health; it causes diarrhea, nausea, vomiting, muscle weakness, low blood pressure etc.

Sulfur is the important nutrient for plant growth as it is a component of vitamins; it reduces the sodium content and helps in formation of enzyme and plant protein. $\mathrm{S}$ is most important for mustard, garlic and onions for the specific flavor. As we know content of different minerals depends upon the crop quality. In present study sulfur content is significantly increased in test soil as compared to organic soil. S deficiency causes yellowing of leaves that similar to $\mathrm{N}$ deficiency. The present study was supported by Linzon S.N.et. al.(2012) who reported that sulfur has very important impact on plant in optimum content, its deficiency or excess can result in deleterious effect. Long term exposures of sulfur may result in acute injury which is localized within the plant leaf, with interveinal lesions usually developing on broad leaves.

Micronutrients $(\mathrm{Cu}, \mathrm{Fe}, \mathrm{B}, \mathrm{Zn}$, and $\mathrm{Mn})$ are also very important for the plant growth which required in trace amount. In present study $\mathrm{Cu}$ significantly increased in test soil as compare to organic soil, and $\mathrm{Zn}, \mathrm{B}, \mathrm{Fe}$, and $\mathrm{Mn}$ significantly decreased in test soil as compare to organic soil. In plants $\mathrm{Cu}$ activates different types of enzyme and promotes plant growth, its deficiency impacts on plant tissue and color. Fe performs various functions in plant like nitrogen reduction, lignin formation and it is a component of various enzymes. $\mathrm{Zn}$ is required for the higher yield in plants. The present study was supported by Khwaja H, et. al. (2017) who suggested that increased concentration of $\mathrm{Zn}$ and $\mathrm{Fe}$ increases micronutrients and also increased seed $\mathrm{Ca}, \mathrm{P}$ and $\mathrm{S}$ content. B is important micronutrient for the plant as it essential for the cell wall formation and also important for the development of reproductive structures. Present study was supported by Gupta U. et.al.(2013) who reported that B deficiency cause many anatomical, physiological and biochemical changes. It also hampers flowering and fruiting by retarding pollen germination and pollen tube development process.

$\mathrm{Mn}$ is a part of enzyme system in plants which associated with photosynthesis. Mn increases $\mathrm{P}$ and $\mathrm{Ca}$ avaibility and hence accelerates germination and maturity. Present study was supported by Mousavi S. et. al.(2011) who reported that Mn deficiency decreases photosynthesis, carbohydrate synthesis therefore it decreases crop yield and quality.

\section{CONCLUSION}

In this study we compared mineral content of polluted soil with organic soil. We found that mineral omposition of soil is changed drastically by irrigation with polluted water. It causes harm to the soil as well as degrades the crop quality. Minerals are important factor 


\section{International Journal of Research in Advent Technology, Vol.7, No.5, May 2019 E-ISSN: 2321-9637 Available online at www.ijrat.org}

which should be present in optimum amount for a good harvest. Soil testing of all the fields is advisable before using them for agricultural purpose. Mineral content is also vary from plant to plant, it is good to test soil before growing particular plant.

\section{ACKNOWLEDGMENTS}

I would like to express my special thanks of gratitude to my guide Dr. Jyoti Dave who gave me opportunity to do this project on the topic Effect of Industrial Effluents on Chemical Composition of Agriculture Soil in Indore (M.P.).I am also very thankful to my H.O.D. Dr. Rekha Gadre who provided insight and expertise that greatly assisted the research. Special thanks to the farmers who cooperated and allowed to use the soil sample from their agricultural field (polluted \& organic soil) for the present study.

\section{REFERENCES}

[1] Cakmak I.2013m, "Magnesium in crop production, food quality and human health", Springer Science + Bussiness Media Dordrech, 368: 1-4.

[2] CarmeisFilho A., Crusicol C., Narcente A., Mauad M., Garcia R.2017 “ influence of potassium level on root and growth and nutrient uptake of upland rice cultivars", Caatingo 30 (1).

[3] Chesin L and Yien C H 1950. Turbidimetric determination of available sulphates. Procedure of Soil Science Society of America, 14: 149-151.

[4] Gupta U., Solanki H. 2013 "Impact of Boron deficiency on plant growth", International journal of Bioassays, 1048-1050.

[5] Khwaja H., Nazrul I., FarhadG.,Cheyenne D., Cherokee D., and Maren J., 2017, " Effect of increased amount of $\mathrm{Fe}, \mathrm{Zn}$, and $\mathrm{Cd}$ on uptake, translocation and accumulation of human health related micronutrients in wheat," Asian J Agric Food Science, 5 (1) : 19-29.

[6] Lindsay, W. L. and Norvell W. A. (1978) Development of DTPA test for Fe, $\mathrm{Zn}, \mathrm{Mn}$, and $\mathrm{Cu}$. Soil Science Society of American Journal, 42: 421428.

[7] Linzon S.N., Temple P.J., Pearson R.G.2012," Sulfur concentration in plant foliage and related effects", Journal of the Air Pollution Control Association, 29:5,520-525.

[8] Mousavi S., Shahsavari M., Rezaei M. 2011 “A general overview on Manganese (Mn) importance for crop production", Australian Journal of Basic and Applied Science,5(9):1799-1803.

[9] Razaq M., Zhang. P, ShenH..2017 "Influence of nitrogen and phosphorous on the growth and root morphology of Acer mono."'Manual Joaquin Reigosa University of Vigo Spain, 12 (2).
[10] Reeuwijk LP. Editor. Procedures for Soil Analysis. 6th edition.-Technical Paper/International Soil Reference and Information Centre,Wageningen, The Netherlands. 2002.

[11] Subbaiah, B.V. and Asija, G.L., A rapid procedure for the estimation of available nitrogen in soil.Curr. Sci., 1956, 25: 259.

[12] Tabatabaeian J. 2014," Effect of calcium nutrition on reducing the effect of salinity on tomato plant", American Journal of Plant Nutrition and Fertilization Technology, 4 (1):11-17.

[13] Walkley A and Black C A 1934. An examination of different methods for determining soil organic matter and a proposed modification of the chromic acid titration method. Soil Science, 37: 29-38. 